\title{
LOW AEROBIC FITNESS IN BRAZILIAN ADOLESCENTS
}

\author{
BAIXA APTIDÃO AERÓBIA EM ADOLESCENTES BRASILEIROS
}

\section{BAJOS NIVELES DE CAPACIDAD AERÓBICA EN ADOLESCENTES DE BRASIL}

\author{
Diego Augusto Santos Silva' \\ (Physical educator) \\ Mark Stephen Tremblay ${ }^{2}$ \\ (Scientist exercise) \\ Andreia Pelegrini ${ }^{3}$ \\ (Physical educator) \\ João Marcos Ferreira de Lima Silva ${ }^{4}$ \\ (Physical educator) \\ Edio Luiz Petroski ${ }^{1}$ \\ (Physical educator)

\section{Federal University of Santa} \\ Catarina, Post-Graduate Program in \\ Physical Education, Florianópolis, \\ SC, Brazil. \\ 2. University of Ottawa, Department \\ of Pediatrics, CHEO Research \\ Institute, Ottawa, Canada. \\ 3. University of the State of Santa \\ Catarina, Post-Graduate Program \\ in Human Movement Science, \\ Florianópolis, SC, Brazil. \\ 4. Faculty Leão Sampaio, Juazeiro \\ do Norte, CE, Brazil.
}

\section{Correspondence:}

Universidade Federal de Santa Catarina. Centro de Desportos. Núcleo de Pesquisa em Cineantropometria e Desempenho Humano. Campus Universitário Trindade, Florianópolis, SC, Brazil. 88040-900. diegoaugustoss@yahoo.com.br

\begin{abstract}
Artículo Original

Introduction: aerobic fitness is considered one of the most important components of health-related physical fitness, with low levels related to increased risk of premature death from all causes, especially cardiovascular diseases. Objective: to identify the characteristics of adolescents at higher risk of low levels of aerobic fitness. Methods: the study included 696 adolescents (15-17 years of age) enrolled in public high schools of Florianópolis, southern Brazil. This cross-sectional epidemiological study was conducted in Florianópolis, Santa Catarina, Brazil. Aerobic fitness was measured using the modified Canadian Aerobic Fitness Test (mCAFT). Sociodemographic (gender, age, school grade, paternal and maternal schooling, socioeconomic status), and anthropometric variables (body weight, height, triceps and subscapular skinfold thickness), sexual maturation, physical activity, sedentary behavior, and eating habits were collected. Results: it was found that $31.5 \%$ of adolescents had low aerobic fitness levels, being higher in boys (49.2\%) compared to girls (20.6\%). Moreover, girls with sedentary behavior, overweight and high body fat percentage were the groups most likely to have inadequate aerobic fitness. In males, the groups most likely to have inadequate aerobic fitness were those whose parents studied more than eight years, those with low levels of physical activity, and those with inadequate nutrition and excessive body fat. Conclusion: low aerobic fitness levels were present in one third of adolescents and was more prevalent in boys. Lifestyle changes, including replacement of sedentary behaviors by physical and sport activities, may assist in improving the aerobic fitness of Brazilian adolescents.
\end{abstract}

Artigo Original

ORIGINAL ARTICLE

Keywords: Physical fitness, Motor activity, Health, Exercise tolerance.

\section{RESUMO}

Introdução: a aptidão aeróbiaé considerada um dos componentes mais importantes da aptidão física relacionada com a saúde, pois seus baixos niveis estão relacionados com o maior risco de morte prematura por todas as causas, especialmente as doenças cardiovasculares. Objetivo: identificar as características dos adolescentes com maior risco de baixos níveis de aptidão aeróbia. Métodos: participaram do estudo 696 adolescentes (15 a 17 anos) matriculados no ensino médio de escolas públicas de Florianópolis, no sul do Brasil. Este estudo epidemiológico transversal foi realizado em Florianópolis, Santa Catarina, Brasil. A aptidão aeróbia foi medida com o Modified Canadian Aerobic Fitness Test (mCAFT). Foram coletadas variáveis sociodemográficas (sexo, idade, série de ensino escolar, escolaridade do paie da mãe, nivel econômico), antropométricas (peso corporal, estatura, dobras cutâneas tricipital e subescapular), maturação sexual, atividade física, comportamento sedentário e hábitos alimentares. Resultados: observou-se que 31,5\% dos adolescentes apresentaram baixos níveis de aptidão aeróbia, sendo maior nos rapazes (49,2\%) com relação às moças (20,6\%). Ademais, as moças com comportamento sedentário, excesso de peso e adiposidade corporal alta foram os grupos com maiores chances de inadequação na resistência aeróbia. No sexo masculino, os grupos com maiores chances de inadequação na aptidão aeróbia foram aqueles cujos pais estudaram mais de oito anos, os pouco ativos fisicamente e os que tinham alimentação inadequada e excesso de adiposidade corporal. Conclusão: os baixos níveis de aptidão aeróbia estavam presentes em um terço dos adolescentes, sendo mais prevalentes nos rapazes. As modificações no estilo de vida, com substituição dos hábitos sedentários pela prática de atividades físicas e esportivas podem ajudar a melhorar a aptidão aeróbia dos adolescentes brasileiros.

Palavras-chave: Aptidão física, Atividade motora, Saúde, Tolerância ao exercício.

\section{RESUMEN}

Introducción: la capacidad aeróbica es considerada uno de los más importantes componentes de la condición física relacionada con la salud, debido a que sus bajos niveles se asocian con un mayor riesgo de muerte prematura por todas las causas, especialmente la enfermedad cardiovascular. Objetivo: identificar las características de los adolescentes con mayor riesgo de bajos niveles de capacidad aeróbica. Métodos: el estudio incluyó a 696 adolescentes (15-17 años) matriculados en la educación secundaria en escuelas públicas en Florianópolis, en el sur de Brasil. Este estudio epidemiológico transversal se realizó en Florianópolis, Santa Catarina, Brasil. La condición física aeróbica se midió con el Modified Canadian Aerobic Fitness Test (mCAFT). Fueron recogidas las variables sociodemográficas (género, edad, serie de la educación escolar, escolaridad del padre y de la madre, nivel socioeconómico), antropométricas (peso, altura, pliegue tricipital y subescapular), la maduración sexual, actividad física, el comportamiento sedentario y los hábitos alimentarios. Resultados: se observó que el 31,5\% de los adolescentes tenía bajos niveles de condición física aeróbica, siendo mayor en los varones $(49,2 \%)$ en comparación con las mujeres $(20,6 \%)$. Además, las mujeres jóvenes con comportamiento sedentario, sobrepeso y grasa corporal alto fueron los grupos más propensos a ser insuficiente en la resistencia aeróbica. 
En los hombres, los grupos más propensos a ser insuficiente en la capacidad aeróbica fueron aquellos cuyos padres tenían más de ocho años de estudio, los que tenían poca actividad física y los que tenían alimentación inadecuada y exceso de grasa corporal. Conclusión: los bajos niveles de capacidad aeróbica estaban presentes un tercio de los adolescentes, siendo más frecuente en los varones. Los cambios en el estilo de vida, con la sustitución de los hábitos sedentarios por la práctica de actividades fisicas y deportivas pueden ayudar a mejorar la capacidad aeróbica de los adolescentes brasileños.

Palabras clave: Aptitud física, Actividad motora, Salud, Tolerancia al ejercicio.

\section{INTRODUCTION}

Aerobic fitness is considered one of the most important components of health-related physical fitness, with low levels related to increased risk of premature death from all causes, and especially cardiovascular diseases ${ }^{1}$. During childhood, unsatisfactory aerobic fitness levels are associated with hyperlipidemia (high total cholesterol and triglycerides levels), high blood pressure, insulin insensitivity and increased risk of obesity ${ }^{2}$. Compelling evidence indicates significant declines in aerobic fitness levels among children and youth over the past few decades $^{1,3}$. For these reasons, it is important to promote and monitor aerobic fitness from an early age.

There is some evidence on the aerobic fitness of Brazilian adolescents ${ }^{4-6}$; however, most of these studies ${ }^{4,6}$ have been done in small towns, with built environments and lifestyle behaviors different from state capitals, which are fundamentally different, more populous, and with increased risk of acquisition of risk factors for the development of chronic diseases ${ }^{7}$. This study aims to fill this scientific gap in relation to the scarcity of studies on aerobic fitness of adolescents living in Brazilian capitals and identify correlates of aerobic fitness in an effort to direct future interventions at subgroups of adolescents who have low aerobic fitness.

\section{METHODS}

This cross-sectional study was conducted in the second half of 2007 in Florianópolis, Santa Catarina, Brazil. Florianópolis is the capital of the state of Santa Catarina, in southern Brazil.

The sampling design included public and state schools and was determined in two stages: (a) stratified by geographic region and (b) school type. In the first stage, the city was divided into five geographical regions: Central, West, East, North and South. Schools with the greatest number of students in each region were selected, and in each school, classes were randomly selected in sufficient number to achieve the representativeness of the geographical area. Thus, one school in each region was selected. In the second stage, all adolescents who were present in class on the day of data collection were invited to participate in the study.

The study population consisted of 12,741 high school students in the city of Florianópolis. Of that number, 4,794 were studying in the City center, 2,460 in West, 813 East, 2,347 North, and 2,327 South. Overall, $58 \%$ of students in these regions were female, and $42 \%$ male.

To calculate the sample size, unknown prevalence for the outcome (50\%), tolerable error of five percentage points, confidence level of 95\% and design effect of 1.5 were adopted, adding 15\% for possible losses and refusals. Thus, it would be necessary to evaluate 643 students. Due to the characteristics of the sampling process, which involved all individuals present in classroom, 696 adolescents participated in the sample.

The study was approved by the Ethics Committee on Human Research of a Brazilian university (Institutional Review Board). All adolescents who participated in the survey delivered the Informed Consent signed by parents or responsible person (for under 18 years of age), or by themselves (18 years).
Exclusion criteria adopted were: (a) $<15$ years and $>18$ years of age, (b) pregnant, (c) presence of any disease that prevented the performance of anthropometric measurements and physical tests, (d) refusal to participate.

Aerobic fitness was measured using the modified Canadian Aerobic Fitness Test (mCAFT), during which respondents had to complete one or more three-minute "stepping" stages (up and down steps with increasing intensity) at predetermined cadences, based on their age and gender ${ }^{3,8,9}$. Respondents' heart rate was recorded after each stage, and the test was completed when heart rate at the end of a stage reached $85 \%$ of their age-predicted maximal heart rate (220 - age). Predicted maximal aerobic power $\left(\mathrm{VO}_{2} \mathrm{max}\right)$ was determined for all participants ${ }^{8}$. Respondents who completed at least one stage, but stopped midway through a subsequent stage ("partials"), were assigned a score based on their last fully completed stage. At the end of the test, an aerobic fitness score was generated: Aerobic Fitness Score $=10 \times\left[17.2+\left(1.29 \times \mathrm{O}_{2}\right.\right.$ uptake $)$ - $(0.09 x$ body weight in $\mathrm{kg})$ - (0.18 $x$ age in years). From this score, each participant was classified into one of five categories related to health benefits: (a) "needs improvement," (b) "fair" (c) "good" (d) "very good" and (e) "excellent". In this study, adequate aerobic fitness was considered for adolescents in categories (c), (d), (e). Participants in categories (a) and (b) were considered as having low aerobic fitness levels. The aerobic fitness test used in this study has been validated in comparison to indirect calorimetry on males and females aged 15-69 years ${ }^{10,11}$.

The following sociodemographic information was used: gender (male and female), age (15-16 years, and 17-18 years); school grade - High school $\left(1^{\text {st }}, 2^{\text {nd }}\right.$ and $\left.3^{\text {rd }}\right)$; paternal and maternal schooling ( $\leq 8$ years and $>8$ years) and socioeconomic status (low and high) according to family purchasing power ${ }^{12}$. The five economic classes " $\mathrm{A}^{\prime \prime},{ }^{\prime \prime} \mathrm{B},{ }^{\prime \prime} \mathrm{C}$, " $\mathrm{D}$ " and " $E$ " represent decreasing order of purchasing power. Participants from classes "A" and "B" were classified as "high" economic level, those from class "C", "D" and "E" as "low" economic level according to the literature ${ }^{13}$.

Physical activity level was determined with the International Physical Activity Questionnaire (IPAQ), short version ${ }^{14,15}$. Adolescents who participated in physical activities of moderate and / or vigorous intensity for 60 minutes at least 5 days/week were considered active ${ }^{16}$.

Sedentary behavior was checked by self-reported time spent watching television on weekdays and weekend days and a weighted daily average determined. Time spent watching TV more than 2 hours / day was considered as a sedentary risk behavior ${ }^{17}$.

Dietary habits were checked from the following item: Do I eat a balanced diet, which is part of the Fantastic Life Style questionnaire that is validated for adolescents (14-19 years old) $)^{8,18}$. The instrument provides an explanation of what is considered a balanced diet. This item presents the following response options: (a) almost never (b) rarely (c) sometimes (d) with relative frequency and (e) almost always. Options (d) and (e) were considered as adequate nutrition and options (a), (b) and (c) as inadequate nutrition.

For the nutritional status assessment, weight and height measures were collected ${ }^{8}$ to calculate the body mass index (BMI). International 
cutoffs for BMI were used ${ }^{19,20}$, according to age and gender. This variable was ranked into normal weight (underweight + normal weight) and overweight (overweight + obesity).

Body adiposity was assessed by triceps and subscapular skinfold thi$\mathrm{ckness}^{8}$, which were measured to the nearest $0.1 \mathrm{~mm}$ using a Cescorf ${ }^{\circledR}$ (CESCORF Sports Equipment Ltd., Porto Alegre, Brazil) scientific caliper. Excess peripheral (triceps skinfold) and central adiposity (subscapular skinfold) was determined using the $90^{\text {th }}$ percentile of the reference distribution for age and gender of the Centers for Disease Control and Prevention curves ${ }^{21}$.

Biological maturation was investigated from the sexual maturation status through Tanner spreadsheets ${ }^{22}$ which considers the analysis of self-reported pubic hair in females and males. No adolescent was found at stage 1. Stages 2, 3 and 4 were grouped into pubertal phase (puberty status) and 5 and 6 into post-pubescent (post-puberty status).

Analyses were stratified by gender using the Stata 11.0 software (StataCorp, College Station, Texas, USA). Data normality was verified using the Kolmogorov-Smirnov test, which showed non-normal distribution of continuous data. The Mann-Whitney $U$ test was used to compare continuous variables between genders. Effect sizes to compare continuous variables between genders were calculated ${ }^{23}$, and classified according to Hopkins et al. ${ }^{24}$. Hopkins et al. ${ }^{24}$ defined effect size as trivial (0.0), small (0.2), intermediate (0.6), large (1.2), very large (2.0), nearly perfect (4.0), and perfect (>4.0).

In the unadjusted and adjusted association analysis, the Wald test and binary logistic regression were applied to estimate odds ratios $(\mathrm{OR})$ and $95 \%$ confidence intervals $(95 \% \mathrm{Cl})$. Regression analysis followed a hierarchical determination model for low aerobic fitness level, hypothetically time-related ${ }^{25}$. Statistical modeling followed division into four groups of variables: a) distal, which included sociodemographic variables (age, socioeconomic status, maternal and parental schooling and school grade), b) intermediate 1, which included health-related behaviors (physical activity, dietary habits and sedentary behavior), c) intermediate 2, which included nutritional status (BMI) and body fat (skinfold thickness), d) proximal, which included stage of sexual maturation. Initially, the variables of the distal block were adjusted to the other factors of the same level and those that remained significant retained. Then, the variables of the intermediate block variables were controlled to the variables of the same level and to those of the distal level that remained in the model. Then, the variables of the intermediate block 2 were controlled to the variables of the same level and to those of intermediate 1 and distal level that remained in the model. Finally, in the analysis of variables of the proximal block, the adjustment was performed to the other factors of intermediate and distal levels that remained in the model. A p-value below 0.20 in the Wald test was adopted as criterion for retaining the factor in the regression analyses. Finally, factors whose $p$-value was less than 0.05 were considered significantly associated with the outcome. All analyses were performed considering the design effect and the sampling weight.

\section{RESULTS}

Summary descriptive statistics with comparisons between females and males are provided in table 1.

Table 2 provides a summary of the proportional distribution of participants for each independent variable.

The prevalence of low aerobic fitness levels in females was 20.6\%, and $49.2 \%$ in males. Females students with sedentary risk behavior, overweight and high body fat had a higher prevalence of low aerobic fitness ( $p$ <.05). For males, those whose parents studied over eight years, had low physical activity, poor diet and high body fat levels were more likely to have low aerobic fitness levels ( $p<0.05)$ (table 3).
Table 1. Summary descriptive characteristics of participants by sex (mean, and standard deviation).

\begin{tabular}{|c|c|c|c|c|c|}
\hline Variables & $\begin{array}{c}\text { Female } \\
(n=432)\end{array}$ & $\begin{array}{c}\text { Male } \\
(n=264)\end{array}$ & $\mathrm{p}$ & Effect-size & \begin{tabular}{|c|c}
$\begin{array}{c}\text { Qualitative } \\
\text { interpretation }\end{array}$ \\
\end{tabular} \\
\hline Age (years) & $16.1(0.9)$ & $16.2(0.9)$ & 0.42 & 0.00 & Trivial \\
\hline $\begin{array}{c}\text { Moderate to vigorous } \\
\text { physical activity } \\
\text { (minutes per week) }\end{array}$ & 757 (737) & $1082(1204)$ & $<0.01^{*}$ & 0.31 & Moderate \\
\hline $\begin{array}{l}\text { Television watching } \\
\text { time (minutes per day) }\end{array}$ & $195(143)$ & $163(150)$ & $<0.01^{*}$ & 0.16 & Trivial \\
\hline Weight $(\mathrm{kg})$ & 54.5 (10.9) & $64.1(11.0)$ & $<0.01^{*}$ & 0.82 & Moderate \\
\hline Height $(\mathrm{cm})$ & $161.1(6.1)$ & $173.2(7.7)$ & $<0.01^{*}$ & 1.72 & Large \\
\hline $\begin{array}{c}\text { Body mass index } \\
\left(\mathrm{kg} / \mathrm{m}^{2}\right)\end{array}$ & $20.1(3.7)$ & $21.4(3.6)$ & 0.17 & 0.08 & Trivial \\
\hline $\begin{array}{l}\text { Triceps skinfold } \\
\text { thickness (mm) }\end{array}$ & $16.8(5.9)$ & $9.9(4.9)$ & $<0.01^{*}$ & 1.22 & Large \\
\hline $\begin{array}{c}\text { Subscapular skinfold } \\
\text { thickness (mm) }\end{array}$ & $14.5(6.8)$ & $10.7(6.7)$ & $<0.01^{*}$ & 0.58 & Small \\
\hline $\begin{array}{l}\text { Sum of skinfold } \\
\text { thickness (mm) }\end{array}$ & $31.4(11.9)$ & $20.7(11.1)$ & $<0.01^{*}$ & 0.93 & Moderate \\
\hline Aerobic fitness score & $417.6(37.3)$ & $491.1(73.3)$ & $<0.01^{*}$ & 1.20 & Large \\
\hline
\end{tabular}

Table 2. Proportional distribution of participants for independent variables by sex.

\begin{tabular}{|c|c|c|c|c|}
\hline \multirow[t]{2}{*}{ Variables } & \multicolumn{2}{|r|}{ Female } & \multicolumn{2}{|r|}{ Male } \\
\hline & $\mathrm{n}$ & $\%(95 \% \mathrm{Cl})$ & $\mathrm{n}$ & $\%(95 \% \mathrm{Cl})$ \\
\hline Total & 432 & $62.0(58.0,65.0)$ & 264 & $38.0(34.5,41.6)$ \\
\hline \multicolumn{5}{|l|}{ Age (years) } \\
\hline $15-16$ & 289 & $66.9(60.1,72.3)$ & 165 & $62.5(57.0,68.9)$ \\
\hline $17-18$ & 143 & $33.1(27.0,35.5)$ & 99 & $37.5(31.3,42.5)$ \\
\hline \multicolumn{5}{|c|}{ Socioeconomic Level } \\
\hline Low & 140 & $35.7(29.9,39.8)$ & 47 & $22.1(16.9,27.6)$ \\
\hline High & 252 & $64.3(59.7,59.7)$ & 166 & $77.9(72.4,83.0)$ \\
\hline \multicolumn{5}{|c|}{ Maternal schooling } \\
\hline$\leq 8$ years & 201 & $49.4(43.5,54.0)$ & 88 & $39.1(33.3,45.6)$ \\
\hline$>8$ years & 206 & $50.6(44.6,56.6)$ & 137 & $60.9(54.3,66.3)$ \\
\hline \multicolumn{5}{|c|}{ Paternal schooling } \\
\hline$\leq 8$ years & 174 & $44.0(38.9,46.7)$ & 77 & $34.8(28.1,40.4)$ \\
\hline$>8$ years & 218 & $55.6(50.8,59.4)$ & 144 & $65.2(59.5,71.5)$ \\
\hline \multicolumn{5}{|l|}{ Grade } \\
\hline 1 & 135 & $30.9(26.3,34.1)$ & 101 & $38.3(32.6,44.1)$ \\
\hline 2 & 185 & $43.0(38.1,47.1)$ & 97 & $36.7(30.1,41.8)$ \\
\hline 3 & 112 & $26.1(22.6,30.5)$ & 66 & $25.0(20.3,30.2)$ \\
\hline \multicolumn{5}{|l|}{ Physical activity } \\
\hline Active & 295 & $71.6(67.2,77.8)$ & 180 & $79.6(74.8,84.9)$ \\
\hline Low active & 117 & $28.4(22.5,34.6)$ & 46 & $20.4(15.0,25.3)$ \\
\hline \multicolumn{5}{|c|}{ Sedentary behavior } \\
\hline$<2$ hours/day & 174 & $41.6(37.0,46.2)$ & 130 & $57.5(51.0,63.5)$ \\
\hline$\geq 2$ hours/day & 244 & $58.4(53.6,62.8)$ & 96 & $42.5(36.3,48.9)$ \\
\hline \multicolumn{5}{|l|}{ Balanced diet } \\
\hline Yes & 114 & $27.5(23.0,31.4)$ & 46 & $19.8(13.8,23.7)$ \\
\hline No & 300 & $72.5(68.3,76.7)$ & 186 & $80.2(75.3,85.4)$ \\
\hline \multicolumn{5}{|l|}{ Nutritional status } \\
\hline Normal & 382 & $88.4(85.7,91.6)$ & 229 & $86.7(82.6,90.6)$ \\
\hline Overweight & 50 & $11.6(8.3,15.4)$ & 35 & $13.3(9.3,17.3)$ \\
\hline \multicolumn{5}{|l|}{ Body adiposity } \\
\hline Normal & 416 & $96.3(94.5,98.0)$ & 245 & $92.8(89.2,95.6)$ \\
\hline High & 16 & $3.7(1.9,5.4)$ & 19 & $7.2(4.0,10.3)$ \\
\hline \multicolumn{5}{|l|}{ Maturation } \\
\hline Pubertal & 221 & $54.2(49.7,60.1)$ & 48 & $19.1(14.6,24.2)$ \\
\hline Post pubertal & 187 & $45.8(39.9,51.6)$ & 203 & $80.9(75.8,85.3)$ \\
\hline
\end{tabular}

Cl: confidence interval. Active: adolescents who participated in physical activities of moderate and / or vigorous intensity for 60 minutes at least 5 days/week; The variable Balanced diet was analyzed according to Fantastic Life Style questionnaire, 18 ; Nutritional status was analyzed according to international cutoffs for BMI19,20; Body adiposity was assessed by triceps and subscapular skinfold thicknes ${ }^{21}$; Biological maturation was investigated from the sexual maturation status through Tanner spreadsheets ${ }^{22}$ 
In the unadjusted analysis (table 4) females with low sedentary risk behavior, overweight, and excess body fat were more likely to have low aerobic fitness levels. After adjustment, female students with sedentary risk behavior; overweight girls and those with excess fat were more likely to have low aerobic fitness levels.

In the unadjusted analysis, males with low level of physical activity, had poor diet or excess body fat were more likely to have low aerobic fitness levels. After adjustment, boys whose parents studied over eight years, those with low physical activity, those with poor diet, and those with excess body fat were more likely to have low aerobic fitness levels (table 4).

Table 3. Prevalence of low aerobic fitness levels according to independent variables.

\begin{tabular}{|c|c|c|c|c|}
\hline \multirow{2}{*}{ Variables } & \multicolumn{2}{|r|}{ Female } & \multicolumn{2}{|r|}{ Male } \\
\hline & $\mathrm{n}$ & $\%(95 \% \mathrm{Cl})$ & $\mathrm{n}$ & $\%(95 \% \mathrm{Cl})$ \\
\hline Total & 89 & $20.6(16.8,24.3)$ & 130 & $49.2(43.3,55.0)$ \\
\hline Age (years) & & $p=0.06^{*}$ & & $\mathrm{p}=0.41^{*}$ \\
\hline $15-16$ & 52 & $18.0(11.6,25.1)$ & 78 & $47.3(40.5,54.4)$ \\
\hline $17-18$ & 37 & $25.9(18.7,33.2)$ & 52 & $52.5(42.5,62.5)$ \\
\hline Socioeconomic Level & & $p=0.30^{*}$ & & $p=0.59^{*}$ \\
\hline Low & 24 & $17.1(11.0,23.7)$ & 25 & $53.2(46.6,60.5)$ \\
\hline High & 54 & $21.4(16.2,26.0)$ & 81 & $48.8(41.1,55.5)$ \\
\hline Maternal schooling & & $p=0.54^{*}$ & & $p=0.91^{*}$ \\
\hline$\leq 8$ years & 39 & $19.4(13.6,24.4)$ & 43 & $48.9(38.8,58.7)$ \\
\hline$>8$ years & 45 & $21.8(15.9,26.9)$ & 68 & $49.6(41.5,53.2)$ \\
\hline Paternal schooling & & $p=0.36^{*}$ & & $p=0.04^{*}$ \\
\hline$\leq 8$ years & 42 & $23.0(18.2,28.9)$ & 31 & $40.3(29.9,50.3)$ \\
\hline$>8$ years & 40 & $19.3(13.3,25.0)$ & 77 & $53.5(45.9,61.7)$ \\
\hline Grade & & $p=0.91^{*}$ & & $p=0.10^{*}$ \\
\hline 1 & 29 & $21.8(14.6,28.0)$ & 45 & $44.6(34.9,53.1)$ \\
\hline 2 & 36 & $19.5(13.7,25.2)$ & 47 & $48.5(38.3,58.5)$ \\
\hline 3 & 24 & $21.4(13.7,29.1)$ & 38 & $57.6(45.3,69.8)$ \\
\hline Physical activity & & $p=0.67 \dagger$ & & $p=0.04 \dagger$ \\
\hline Active & 60 & $20.3(11.0,19.2)$ & 84 & $46.7(40.3,53.9)$ \\
\hline Low active & 26 & $22.2(16.9,28.7)$ & 29 & $63.0(51.1,76.4)$ \\
\hline Sedentary behavior & & $p=0.03^{*}$ & & $p=0.70^{*}$ \\
\hline$<2$ hours/day & 28 & $16.1(10.6,21.5)$ & 63 & $48.5(40.0,56.7)$ \\
\hline$\geq 2$ hours/day & 60 & $24.6(19.6,29.9)$ & 49 & $51.0(42.1,61.0)$ \\
\hline Balanced diet & & $p=0.74 \dagger$ & & $p<0.01 \dagger$ \\
\hline Yes & 23 & $20.2(13.0,27.7)$ & 14 & $30.4(16.4,43.5)$ \\
\hline No & 65 & $21.7(16.9,26.0)$ & 100 & $53.8(46.5,60.2)$ \\
\hline Nutritional status & & $p<0.01 \dagger$ & & $p=0.31 \dagger$ \\
\hline Normal & 55 & $14.4(11.0,17.8)$ & 110 & $48.0(42.4,55.0)$ \\
\hline Overweight & 34 & $68.0(55.3,81.0)$ & 20 & $57.1(41.2,73.9)$ \\
\hline Body adiposity & & $p<0.01 \dagger$ & & $p<0.01 \dagger$ \\
\hline Normal & 75 & $18.0(14.4,21.6)$ & 115 & $46.9(40.2,52.7)$ \\
\hline High & 14 & $87.5(67.1,99.8)$ & 15 & $78.9(61.3,94.3)$ \\
\hline Maturation & & $p=0.81 \dagger$ & & $p=0.41 \dagger$ \\
\hline Pubertal & 47 & $21.3(16.2,26.9)$ & 21 & $43.8(29.7,56.5)$ \\
\hline Post pubertal & 38 & $20.3(14.9,26.3)$ & 119 & $50.2(44.3,59.8)$ \\
\hline
\end{tabular}
Cl: confidence interval; ${ }^{*}$ Linear trend chi-square test ; † Heterogeneity chi-square test; Active: adolescents who participated in physical activities of moderate and / or vigorous intensity for 60 minutes at least 5 days/week; The variable Balanced diet was analyzed according to Fantastic Life Style questionnaire, was analyzed according to international cutoffs for BMI ${ }^{19,20}$; Body adiposity was assessed by triceps and subscapular skinfold thickness ${ }^{21}$; Biological maturation was investigated from the sexual maturation status through Tanner spreadsheets ${ }^{22}$

\section{DISCUSSION}

The prevalence of low aerobic fitness levels identified in this study was similar to that identified in research conducted elsewhere in Brazil state, where $35.4 \%$ of adolescents aged 14 to 17 years had inadequate aerobic fitness levels ${ }^{6}$. However, the prevalence of low aerobic fitness levels in adolescents in the present study from Florianópolis, Brazil was lower than that reported in American children from California ${ }^{26}$, where approximately $45 \%$ of the students had inadequate aerobic fitness levels. Compared with data from Western Santa Catarina, Brazil, the
Table 4. Estimated odds ratios and 95\% confidence intervals for associations between low aerobic fitness levels and independent variables by sex.

\begin{tabular}{|c|c|c|c|c|c|c|c|c|}
\hline \multirow{3}{*}{ Variable } & \multicolumn{4}{|c|}{ Female } & \multicolumn{4}{|c|}{ Male } \\
\hline & \multicolumn{2}{|c|}{ Crude analysis } & \multicolumn{2}{|c|}{$\begin{array}{l}\text { Adjusted } \\
\text { analysis* }\end{array}$} & \multicolumn{2}{|c|}{ Crude analysis } & \multicolumn{2}{|c|}{$\begin{array}{l}\text { Adjusted } \\
\text { analysis* }\end{array}$} \\
\hline & $\begin{array}{c}\text { OR } \\
(95 \% \mathrm{Cl})\end{array}$ & $p$ & $\begin{array}{c}\text { OR } \\
(95 \% \mathrm{Cl})\end{array}$ & $p$ & $\begin{array}{c}\text { OR } \\
(95 \% \mathrm{CI})\end{array}$ & $\mathrm{p}$ & $\begin{array}{c}\text { OR } \\
(95 \% \mathrm{Cl}) \\
\end{array}$ & $p$ \\
\hline Age (years) ${ }^{1}$ & & 0.06 & & 0.11 & & 0.40 & & 0.95 \\
\hline $15-16$ & 1.0 & & 1.0 & & 1.0 & & 1.0 & \\
\hline $17-18$ & $\begin{array}{c}1.5 \\
(0.9,2.5) \\
\end{array}$ & & $\begin{array}{c}1.5 \\
(0.9,2.4) \\
\end{array}$ & & $\begin{array}{c}1.2 \\
(0.7,2.0) \\
\end{array}$ & & $\begin{array}{c}0.9 \\
(0.4,2.0) \\
\end{array}$ & \\
\hline $\begin{array}{c}\text { Socioeconomic } \\
\text { Level }^{1}\end{array}$ & & 0.30 & & 0.34 & & 0.59 & & 0.68 \\
\hline Low & 1.0 & & 1.0 & & 1.0 & & 1.0 & \\
\hline High & $\begin{array}{c}1.3 \\
(0.8,2.2) \\
\end{array}$ & & $\begin{array}{c}1.3 \\
(0.7,2.3) \\
\end{array}$ & & $\begin{array}{c}0.8 \\
(0.4,1.6) \\
\end{array}$ & & $\begin{array}{c}0.6 \\
(0.4,1.7) \\
\end{array}$ & \\
\hline $\begin{array}{c}\text { Maternal } \\
\text { schooling }\end{array}$ & & 0.54 & & 0.40 & & 0.91 & & 0.81 \\
\hline$\leq 8$ years & $\begin{array}{c}0.8 \\
(0.5,1.4) \\
\end{array}$ & & $\begin{array}{c}0.7 \\
(0.4,1.4) \\
\end{array}$ & & $\begin{array}{c}0.9 \\
(0.5,1.6) \\
\end{array}$ & & $\begin{array}{c}1.1 \\
(0.5,2.2) \\
\end{array}$ & \\
\hline$>8$ years & 1.0 & & 1.0 & & 1.0 & & 1.0 & \\
\hline $\begin{array}{c}\text { Paternal } \\
\text { schooling }\end{array}$ & & 0.36 & & 0.39 & & 0.06 & & 0.04 \\
\hline$\leq 8$ years & $\begin{array}{c}1.2 \\
(0.7,2.0) \\
\end{array}$ & & $\begin{array}{c}1.3 \\
(0.7,2.0) \\
\end{array}$ & & \begin{tabular}{c|}
0.6 \\
$(0.3,1.1)$ \\
\end{tabular} & & $\begin{array}{c}0.6 \\
(0.3,0.9) \\
\end{array}$ & \\
\hline$>8$ years & 1.0 & & 1.0 & & \begin{tabular}{|l|}
1.0 \\
\end{tabular} & & 1.0 & \\
\hline Grade $^{1}$ & & 0.85 & & 0.60 & & 0.26 & & 0.14 \\
\hline 1 & 1.0 & & 1.0 & & 1.0 & & 1.0 & \\
\hline 2 & $\begin{array}{c}0.8 \\
(0.5,1.5) \\
\end{array}$ & & $\begin{array}{c}0.7 \\
(0.4,1.4) \\
\end{array}$ & & $\begin{array}{c}1.1 \\
(0.6,2.0) \\
\end{array}$ & & $\begin{array}{c}1.1 \\
(0.6,2.0) \\
\end{array}$ & \\
\hline 3 & $\begin{array}{c}0.9 \\
(0.5,1.8) \\
\end{array}$ & & $\begin{array}{c}0.6 \\
(0.3,1.6) \\
\end{array}$ & & $\begin{array}{c}1.6 \\
(0.9,3.1) \\
\end{array}$ & & $\begin{array}{c}1.9 \\
(0.9,4.0)\end{array}$ & \\
\hline Physical activity ${ }^{2}$ & & 0.67 & & 0.98 & & 0.05 & & 0.04 \\
\hline Active & 1.0 & & 1.0 & & 1.0 & & 1.0 & \\
\hline Low active & $\begin{array}{c}1.1 \\
(0.6,1.8) \\
\end{array}$ & & $\begin{array}{c}0.9 \\
(0.5,1.7) \\
\end{array}$ & & $\begin{array}{c}1.9 \\
(1.1,3.7) \\
\end{array}$ & & $\begin{array}{c}2.0 \\
(1.0,4.1) \\
\end{array}$ & \\
\hline $\begin{array}{l}\text { Sedentary } \\
\text { behavior }^{2}\end{array}$ & & 0.03 & & 0.02 & & 0.70 & & 0.87 \\
\hline$<2$ hours/day & 1.0 & & 1.0 & & 1.0 & & 1.0 & \\
\hline$\geq 2$ hours/day & $\begin{array}{c}1.7 \\
(1.1,2.8) \\
\end{array}$ & & $\begin{array}{c}1.8 \\
(1.1,2.9) \\
\end{array}$ & & $\begin{array}{c}1.1 \\
(0.6,1.9) \\
\end{array}$ & & $\begin{array}{c}1.1 \\
(0.6,1.8) \\
\end{array}$ & \\
\hline Balanced diet ${ }^{2}$ & & 0.74 & & 0.86 & & $<0.01$ & & $<0.01$ \\
\hline Yes & 1.0 & & 1.0 & & 1.0 & & 1.0 & \\
\hline No & $\begin{array}{c}1.1 \\
(0.6,1.9) \\
\end{array}$ & & $\begin{array}{c}1.1 \\
(0.6,1.8) \\
\end{array}$ & & $\begin{array}{c}2.6 \\
(1.3,5.3) \\
\end{array}$ & & $\begin{array}{c}3.1 \\
(1.4,6.5) \\
\end{array}$ & \\
\hline Nutritional status $^{3}$ & & $<0.01$ & & $<0.01$ & & 0.31 & & 0.66 \\
\hline \begin{tabular}{c|} 
Normal \\
\end{tabular} & 1.0 & & 1.0 & & 1.0 & & 1.0 & \\
\hline Overweight & $\begin{array}{c}12.6 \\
(6.5,24.4) \\
\end{array}$ & & $\begin{array}{c}8.0 \\
(3.7,17.0) \\
\end{array}$ & & $\begin{array}{c}1.4 \\
(0.7,2.9) \\
\end{array}$ & & $\begin{array}{c}0.7 \\
(0.2,2.4) \\
\end{array}$ & \\
\hline Body adiposity ${ }^{3}$ & & $<0.01$ & & 0.04 & & 0.01 & & 0.04 \\
\hline Normal & 1.0 & & \begin{tabular}{|l|}
1.0 \\
\end{tabular} & & 1.0 & & 1.0 & \\
\hline High & $\begin{array}{c}31.8 \\
(7.0,80.9) \\
\end{array}$ & & $\begin{array}{c}5.2 \\
(1.1,27.2) \\
\end{array}$ & & $\begin{array}{c}4.2 \\
(1.4,13.1)\end{array}$ & & $\begin{array}{c}3.9 \\
(1.1,14.2) \\
\end{array}$ & \\
\hline Maturation $^{4}$ & & 0.82 & & 0.91 & & 0.41 & & 0.46 \\
\hline Pubertal & 1.0 & & 1.0 & & 1.0 & & 1.0 & \\
\hline Post pubertal & $\begin{array}{c}0.9 \\
(0.6,1.5) \\
\end{array}$ & & $\begin{array}{c}0.9 \\
(0.6,1.7) \\
\end{array}$ & & $\begin{array}{c}1.3 \\
(0.7,2.4) \\
\end{array}$ & & $\begin{array}{c}1.3 \\
(0.6,2.8) \\
\end{array}$ & \\
\hline
\end{tabular}

OR: odds ratio; Cl: confidence interval; *Adjusted Analysis: All variables were included in the adjusted analysis regardless of $p$-value in the crude analysis. Model variables were retained with $p$-value $\leq 0.20$; superscript numbers (1,2,3, and 4) represent input of variables in the hierarchical model for the adjusted analysis; Active: adolescents who participated in physical activities of moderate and / or vigorous intensity for 60 minutes at least 5 days/week; The variable Balanced diet was analyzed according to Fantastic Life Style questionnaire, 18 . least 5 days/week; The variable Balanced diet was analyzed according to Fantastic Life Style questionnaire,
Nutritional status was analyzed according to international cutoffs for BMI triceps and subscapular skinfold thickness ${ }^{21}$; Biological maturation was investigated from the sexual maturation status through Tanner spreadsheets ${ }^{22}$

present study found lower prevalence of low aerobic fitness levels, as in Western Santa Catarina, 45.8\% of schoolchildren aged 14 to 17 years had inadequate aerobic fitness levels ${ }^{4}$.

In this study was identified a larger percentage of boys than girls with low levels of aerobic fitness. This finding runs counter to most other studies ${ }^{6,26}$. It also runs counter to the findings showing boys report more time in physical activity. There are a few possible explanations for these findings. First, we always need to accept the possibility that the findings are valid and legitimately in conflict with other findings. 
This may be a result of many factors (e.g. underlying behavioral differences, stepping efficiency, physiological differences) between genders. More likely, the standards set for females are lower than those for males, making it easier for females to meet an acceptable standard. That these standards are different does not mean they are not valid, as the relationship between fitness and health differs between genders. Note the actual calculated fitness score (table 1) for females in this sample is much lower than males. Indeed as a final explanation, the relationship between physical activity and fitness in children and adolescents is very unclear ${ }^{27}$.

In this study, it was identified that girls with sedentary risk behavior were more likely to have low aerobic fitness levels. The finding of this study is consistent with a recent systematic review that reported an inverse relationship between sedentary behavior and physical fitness levels in school-aged children and youth ${ }^{28}$.

For boys in the present study, it was identified that low physical activity levels were associated with inadequate aerobic fitness levels. Physical activity is a modifiable lifestyle factors that, if increased, could increase fatigue tolerance and aerobic fitness ${ }^{2}$. For this reason, the regular practice of physical and sports activities at school, home and in the community should be encouraged from early age.

Poor diet was one of the lifestyle factors that was associated with low aerobic fitness levels in boys in the present study. The high intake of fried foods, with low fiber and vitamin contents and an imbalance in the intake of micro and macro nutrients can influence the mood, energy and motivation for physical activity ${ }^{3}$. Cuenca-Garcia et al. ${ }^{3}$ analyzed data from the HELENA study, conducted in eight European cities and reported that high aerobic fitness levels were associated with higher consumption of total energy and cereals among boys.

This study also found an association between high paternal schooling and low aerobic fitness level for males. Families where parents have low education level have difficulty in accessing cultural heritage and not so easily access and interact with media, since such resources are still expensive in Brazi ${ }^{29}$. The interrelationship between social class and aerobic fitness has been previously studied with results similar to those of the present study ${ }^{30}$. One possible explanation for this may be the fact that wealthier families have greater purchasing power and acquire more electronic equipment such as computers, video games and televisions than poorer families, and this increased purchasing power favors increasingly sedentary activities, low physical activity levels and consequently low aerobic fitness ${ }^{30}$.

As in other studies ${ }^{2,4}$, young men and women who were overweight, obese, or having excess body fat, were more likely to have low aerobic fitness levels. The low involvement in sports and physical activities is among the problems to health caused by excess body fat, which leads to lower aerobic fitness levels². Additionally, low body fat and high aerobic fitness levels are associated with positive health indicators, exerting a favorable effect on health during childhood and adolescence ${ }^{26}$.

Investigating aerobic fitness through a field test can be a limitation of this study. Another limitation of the study was the cross-sectional design that does not allow identifying the causal relationship between variables.

\section{CONCLUSIONS}

We conclude that Brazilian girls with sedentary behavior, overweight and high body fat were the groups most likely to have inadequate aerobic fitness. In boys, the groups most likely to have inadequate aerobic fitness were those whose parents studied more than eight years, had low levels of physical activity, and those with inadequate nutrition and excess body fat. Lifestyle changes, including physical and sport activities may assist in improving the aerobic fitness of Brazilian adolescents.

All authors have declared there is not any potential conflict of interests concerning this article.

\section{REFERENCES}

1. Tomkinson GR, Olds TS. Secular changes in pediatric aerobic fitness test performance: the global picture. Med Sport Sci. 2007;50:46-66.

2. Galavíz KI, Tremblay MS, Colley R, Jáuregui E, López y Taylor J, Janssen I. Associations between physical activity, cardiorespiratory fitness, and obesity in Mexican children. Salud Publica Mex. 2012;54(5):463-9.

3. Cuenca-García M, Ortega FB, Huybrechts I, Ruiz JR, González-Gross M, Ottevaere C, et al. Cardiorespiratory fitness and dietary intake in European adolescents: the Healthy Lifestyle in Europe by Nutrition in Adolescence study. Br J Nutr. 2012;107(12):1850-9.

4. Silva DA, Gonçalves EC, Grigollo LR, Petroski EL. Factors associated with low levels of lumbar strength in adolescents in Southern Brazil. Rev Paul Pediatr. 2014;32(4):360-6.

5. Andrade S, Ochoa-Avilés A, Lachat C, Escobar P, Verstraeten R, Van Camp J, et al. Physical fitness among urban and rural Ecuadorian adolescents and its association with blood lipids: a cross sectional study. BMC Pediatr. 2014;14:106.

6. Petroski EL, da Silva AF, Rodrigues AB, Pelegrini A. Health-related physical fitness in Brazilian adolescents from areas having a medium/low Human Development Index. Rev Salud Publica (Bogota). 2011;13(2):219-28.

7. Brazilian Institute of Geography and Statistics (IBGE). IBGE cities. Available at: http://cidades.ibge.gov. $\mathrm{br} / \mathrm{xtras} /$ home.php. Acessed on 08.04.2013.

8. Canadian Society for Exercise Physiology. The canadian physical activity, fitness and lifestyle approach (CPAFLA). 3th ed. Ottawa: Canadian Society for Exercise Physiology; 2003.

9. Tremblay MS, Shields M, Laviolette M, Craig CL, Janssen I, Connor Gorber S. Fitness of Canadian children and youth: results from the 2007-2009 Canadian Health Measures Survey. Health Rep. 2010;21(1):7-20.

10. Weller IM, Thomas SG, Corey PN, Cox MH. Prediction of maximal oxygen uptake from a modified Canadian aerobic fitness test. Can J Appl Physiol. 1993;18(2):175-88.

11. Weller IM, Thomas SG, Gledhill N, Paterson D, Quinney A. A study to validate the modified Canadian Aerobic Fitness Test. Can J Appl Physiol. 1995;20(2):211-21

12. Brazilian Association of Research Companies. Brazil economic classification criterion. 2003. Disponível em: www.abep.org. [Acessado em: 06.03.2005].

13. Silva DA, de Lima LR, Dellagrana RA, Bacil ED, Rech CR. High blood pressure in adolescents: prevalence and associated factors. Cien Saude Colet. 2013;18(11):3391-400.

14. Craig CL, Marshall AL, Sjöström M, Bauman AE, Booth ML, Ainsworth BE, et al. International physical activity questionnaire: 12-country reliability and validity. Med Sci Sports Exerc. 2003;35(8):1381-95.
15. Guedes DP, Lopes CC, Guedes JE. Reproducibility and validity of the International Physical Activity Questionnaire in adolescents. Rev Bras Med Esporte. 2005;11(2):151-8.

16. Strong WB, Malina RM, Blimkie CJ, Daniels SR, Dishman RK, Gutin B, et al. Evidence based physica activity for school-age youth. J Pediatr. 2005;146(6):732-7.

17. American Academy of Pediatrics. Committee on Public Education. American Academy of Pediatrics: Children, adolescents, and television. Pediatrics. 2001;107(2):423-6.

18. Tempestti C, Alfaro S, Cappelen L. Lifestyles and eating habits among in-school adolescents from urban and rural areas in Salta, 2010. Actual Nutr. 2013;14(2):133-40.

19. Cole TJ, Bellizzi MC, Flegal KM, Dietz WH. Establishing a standard definition for child overweight and obesity worldwide: international survey. BMJ. 2000;320(7244):1240-3.

20. Cole TJ, Flegal KM, Nicholls D, Jackson AA. Body mass index cut offs to define thinness in children and adolescents: international survey. BMJ. 2007;335(7612):194.

21. Addo OY, Himes JH. Reference curves for triceps and subscapular skinfold thicknesses in US children and adolescents. Am J Clin Nutr. 2010;91(3):635-42.

22. Tanner JM. Growth at adolescence. Oxford: Blackwell; 1962.

23. Cohen J. Statistical power analysis for the behavioral sciences. 2nd ed. Hillsdale: Lawrence Earlbaum Associates; 1988.

24. Hopkins WG, Marshall SW, Batterham AM, Hanin J. Progressive statistics for studies in sports medicine and exercise science. Med Sci Sports Exerc. 2009;41(1):3-13.

25. Victora CG, Huttly SR, Fuchs SC, Olinto MT. The role of conceptual frameworks in epidemiological analysis: a hierarchical approach. Int J Epidemiol. 1997;26(1):224-7.

26. Malina RM. Physical fitness of children and adolescents in the United States: status and secular change. Med Sport Sci. 2007;50:67-90

27. Armstrong N. Aerobic fitness and physical activity in children. Pediatr Exerc Sci. 2013;25(4):548-60.

28. Tremblay MS, LeBlanc AG, Kho ME, Saunders TJ, Larouche R, Colley RC, et al. Systematic review of sedentary behaviour and health indicators in school-aged children and youth. Int J Behav Nutr Phys Act. 2011;8:98

29. Silva DA. Socioeconomic inequalities in abdominal obesity in Brazilian female adolescents: a nationalbased study. Eur J Pediatr. 2013;172(12):1665-70.

30. Muthuri SK, Wachira LJ, Leblanc AG, Francis CE, Sampson M, Onywera VO, et al. Temporal trends and correlates of physical activity, sedentary behaviour, and physical fitness among school-aged children in Sub-Saharan Africa: a systematic review. Int J Environ Res Public Health. 2014;11(3):3327-59. 